\title{
CARNIVOROUS PLANT SYSTEMATICS
}

Priv.-Doz. Dr. JAN SCHLAUER •ZMBP University of Tübingen • Auf der Morgenstelle 5 •D-72076 Tübingen • Germany • jan@ carnivorousplants.org

Keywords: systemics, phylogeny, taxonomic composition, geographic distribution, carnivorous plants - general

As can be expected in an ecologically defined group of organisms, carnivorous plants (unlike orchids or cacti) do not constitute one single natural taxonomic unit marked by common descent and close interrelationship. On the contrary, several lines (derived from four different orders of flowering plants) have given rise to carnivorous families or genera (see Figure 1). The classification of at least some carnivorous families is not settled yet, so a somewhat extended discussion of different lines of evidence shall be presented here. A suitable starting point for phylogenetic reconstruction (which alone can lead to a natural system) is the question of geographic origin of the groups investigated. On the other hand, fossilized remnants of phylogenetic ancestors hint at the localization and course of evolution of these groups. Chorological (biogeographic) considerations as well as morphological and chemical comparison are established standard methods in biosystematic research, more recently augmented by data from DNA sequence comparison. Taxonomy at species level or below is the task of botanical monographs and cannot be discussed in detail here. Numbers of commonly recognized species in each group are given in bold face.

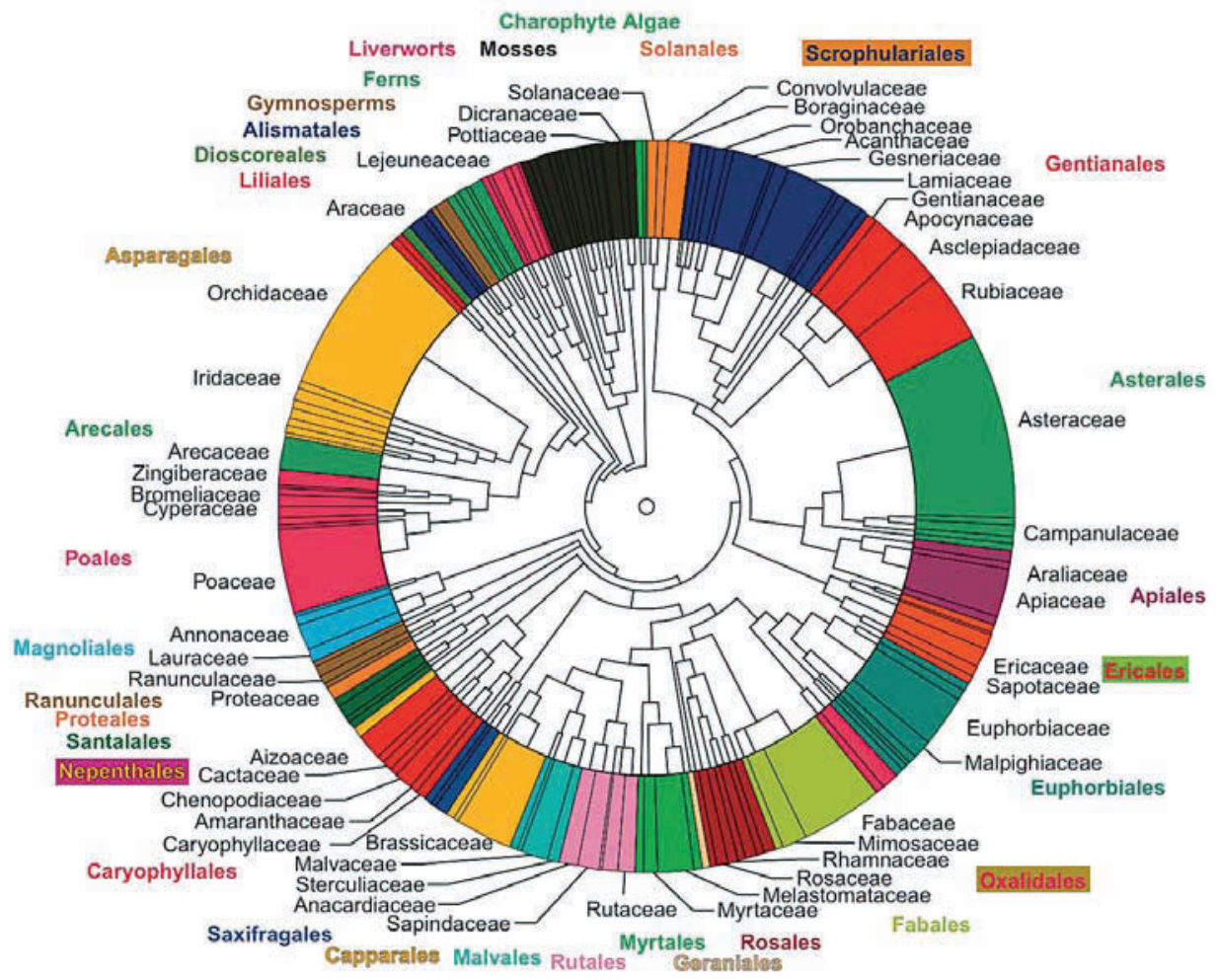

Figure 1: Phylogenetic tree of plant families, sector size approximately corresponding to number of taxa contained. Names of orders containing carnivorous plants are boxed. 
carnivorous families is not settled yet, so a somewhat extended discussion of different lines of evidence shall be presented here. A suitable starting point for phylogenetic reconstruction (which alone can lead to a natural system) is the question of geographic origin of the groups investigated. On the other hand, fossilized remnants of phylogenetic ancestors hint at the localization and course of evolution of these groups. Chorological (biogeographic) considerations as well as morphological and chemical comparison are established standard methods in biosystematic research, more recently augmented by data from DNA sequence comparison. Taxonomy at species level or below is the task of botanical monographs and cannot be discussed in detail here. Numbers of commonly recognized species in each group are given in bold face.

\section{Rosopsida (true dicotyledons) - Caryophyllidae (pinks, cacti) - Nepenthales (see Figure 2)}

\section{Droseraceae}

The Droseraceae, so well known for their widespread representatives in the temperate zone, are one of the most complicated and disputed families of carnivorous plants as far as generic composition and macrosystematic affiliation are concerned. Before a phylogenetic reconstruction can be tried, the generic composition should be established. Here we already meet considerable difficulties. The genus Byblis, which was formerly included in Droseraceae (Bentham \& Hooker 1862-1883), was shown to have more compelling similarities with Pittosporaceae, and it was grouped as a separate family close to the latter in most recent systems. DNA sequence comparison, not confirming a pittosporacean alliance, does still support ample distinctness between Byblis and Droseraceae. Phytochemical evidence quite unambiguously proves Byblis to belong to Scrophulariales (v.i.). The sub-carnivorous Roridula had a fate comparable to Byblis, and this genus is also excluded from Droseraceae (usually placed near Ericales) in recent systems. Traditionally, the genera Drosophyllum (v.i.), Dionaea (1), Aldrovanda (1), and Drosera (153) constituted the Droseraceae of conventional usage. Considerable differences in floral morphology (stamina many $v s$. equal in number to petals and sepals; placentation basal or axial vs. parietal) separate Drosophyllum and Dionaea from Aldrovanda and Drosera, but the striking similarity between the traps of Dionaea and Aldrovanda supports at least the inclusion of Dionaea into a droseracean core group. This is fully corroborated by pollen morphology (Takahashi \& Sohma 1982) and DNA sequence comparison (Williams et al. 1994). On the other hand, almost every character beyond carnivory (woody habit, glandular trichomes on the abaxial leaf surface, reverse circinal vernation, pollen in monads, pantoporate, placentation axial) contradicts inclusion of Drosophyllum in this core group. In conformity to gene sequence data obtained recently (Meimberg et al. 2000), this genus is excluded from Droseraceae and placed closer to Triphyophyllum (Dioncophyllaceae). The subdivision of Droseraceae into several families (Chrtek et al. 1989) seems unjustified beyond the exclusion of Drosophyllum. The exact branching pattern between the three retained genera of Droseraceae is still somewhat disputed, rbcL gene data obtained for a large set of species (Rivadavia et al. 2003; see Figure 3) support a sister relationship of Aldrovanda and Drosera as indicated by floral morphology, Dionaea being basal in the family, while an analysis of four genes from a more limited taxa sample (Cameron et al. 2002) favours a sister relationship of the snap trap genera Aldrovanda and Dionaea, Drosera being more remote.

Fossil pollen has been attributed to several genera of Droseraceae. A single record from central European Mid Miocene (called Fischeripollis) has been assigned to Dionaea (Krutzsch 1970). An interesting series of fossil seeds and even leaves (perhaps traps, if the interpretation is correct) could be established since Senonian for Aldrovanda (Degreef 1997; Schlauer 1997a), occurring through large parts of temperate Eurasia (which used to have a warmer climate than nowadays, and which lacks Aldrovanda in great parts now) with several different and now extinct species and genera (Saxonipollis). This is in very good consonance with the widely scattered distribution of the recent species Aldrovanda vesiculosa throughout the old world, resulting from 
glacial fragmentation of a formerly continuous range. Droseraceae pollen is represented in the Early Tertiary strata of central Australia (Truswell \& Marchant 1986). Mid Palaeocene pollen specimens from Assam (Cherra formation, Droseridites parvus, Sah \& Dutta 1974) are of uncertain attribution but could also belong to Nepenthes ( $N$. khasiana being at least geographically a very close recent species, v.i.). Drosera pollen has been recorded since Lower Miocene from New Zealand (Mildenhall 1980). Miocene pollen (as Droserapollis and Droserapites) of somewhat uncertain droseracean affinity has been found in Taiwan (Huang 1978). Several finds of Tertiary pollen (since Mid Miocene) from Europe have been assigned to either Drosera (Droserapollis) or Nepenthes (Droseridites, Krutzsch 1985). It is, however, unlikely that the recent species of Drosera existed in Europe before Pliocene (v.i.). Probably, the earlier fossils may be attributed to now extinct lines of Droseraceae or even other families. Anyway, the fossil record of Droseraceae pollen is the richest of any carnivorous plant family, and it testifies a wide distribution at least of the progenitors of Aldrovanda since Late Cretaceous.

Dionaea, now restricted to the southeastern United States but possibly present in Europe in the Tertiary, shows primitive traits and an obviously relict range, indicative of high phylogenetic age. It may well be that it is the remnant of a very ancient evolutionary line in Droseraceae dating back to the (possibly Late Cretaceous) origin of the family. The geographic location of origin remains obscure, as displacements and extinctions have certainly occurred. Dionaea has $2 \mathrm{n}=30$ chromosomes.

Aldrovanda, with traps strikingly similar to those of Dionaea but in floral morphology very close to Drosera, might occupy an intermediate generic position both phylogenetically and geographically. The fossil evidence shows an intense process of diversification throughout the Tertiary period but only one of the emergent species was able to survive the Pleistocene and to occupy the present area of the genus. The place of origin is, like in Dionaea, rather uncertain. Aldrovanda has $2 \mathrm{n}=38$ chromosomes.

While the phylogenetic roots of the two foregoing genera could have originated in the northern hemisphere, recent species distribution and diversity indicates an Austral accent in Drosera (for a taxonomic subdivision, see Schlauer 1996), which is revealed in the occurrence of all apparent palaeoendemics (D. meristocaulis, D. regia, D. arcturi) scattered throughout the southern hemisphere plus tropical America. In this respect, the extant fossil record (especially the European Miocene specimens) is somewhat puzzling. The mentioned, probably most primitive species (with undivided styles and pollen predominantly of primitive operculate types) show a typically Gondwanan distribution (Gondwana is the name of a supercontinent composed of what is now South America, Africa, India, and Australia that existed until approximately 100 MYA). This could reflect a very old (Cretaceous) age of the genus, and therefore, of the whole family, dating back to stages of tectonic development when South America, Africa, and Australia were in closer proximity to each other than nowadays. The primitive status of D. regia is fully confirmed by gene sequence similarity (Williams et al. 1994; Rivadavia et al. 2003).

Thelocalyx (2), a group of probably higher advancedness but uncertain descent (marked by a uniformly pentamerous gynoecium and pollen of a unique intermediate type with 20-30 pores

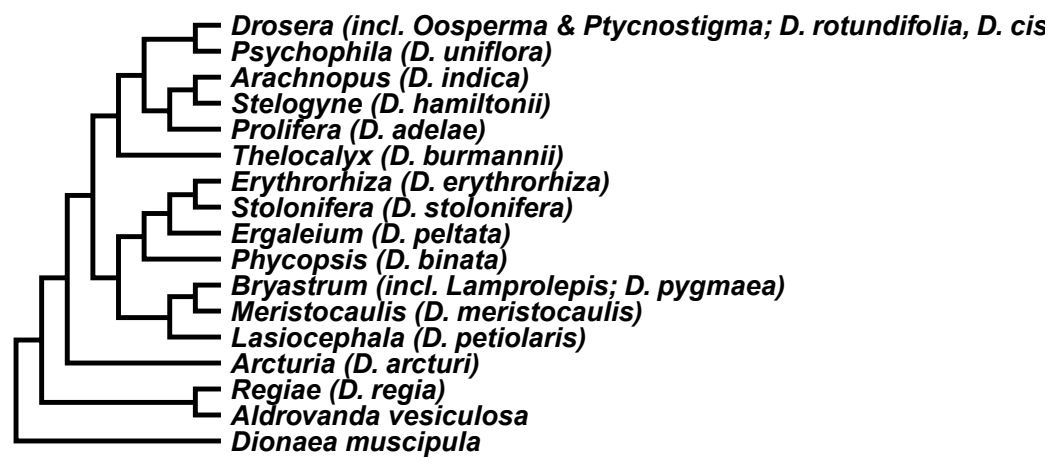

Figure 3: Phylogenetic tree of Droseraceae 
scattered on the proximal face), shows a similarly disjunct distribution with one species (D. burmannii) in the tropics of Asia and Australia and the other (D. sessilifolia) in tropical South America. Genetic analysis (Rivadavia et al. 2003) places Thelocalyx close to the derived (and widespread) clades characterized by three basally split styles.

Judging from recent species, Australia is a (perhaps secondary) center of diversity of the genus (Schlauer 2000), and most of the more recent lines of Drosera can be assumed to have originated here. With the remarkable exception of Coelophylla, all of them share derived pollen types with a single proximal pore.Two predominantly Australian groups are composed of species with corms (subgen. Ergaleium, 40, only one line of which, consisting of the variable D. peltata, leaving Australia to reach New Zealand and Asia, and the closely related species $D$. insolita being rather isolated in Africa) and of species that form tight stipule clusters and propagate by asexual gemmae from transformed leaves (Bryastrum, 30, of which only D. pygmaea reaches also New Zealand). These two very distinct groups obviously show adaptation to a dry climate, which seems a logical consequence of northward moving Australia, thereby entering the subtropical desert belt. Both groups are involved in vivacious speciation processes, which is reflected by frequent cases of sterility (probably caused by hybridogenic origin from incompatible parent species) and morphological overlap (reticulate character distribution) especially in southwest Australia, the core of species diversity. A fundamental genetic instability due to diffused centromeric chromosome organization (Hoshi \& Kondo 1998a \& b) is possibly facilitating diversification by chromosome loss, fragmentation, and fusion. Chromosome counts are consequently somewhat puzzling in these groups. Bryastrum includes species with complements of $6,7,8,10,12,14,16,18,20$, and 28 chromosomes, and most notably for the disjunct $D$. pygmaea counts of $2 n=32$ and 64 have been obtained. Ergaleium contains species with 14, 20, 24, 26, 28, 28, 30, 32, and 40 chromosomes.

On the other hand, the northernmost portion of Australia entered the tropical humid zone only recently, and some tropical members of Drosera may either have invaded this new habitat from the north (New Guinea or the Asian mainland: perhaps sect. Arachnopus - 1, and D. burmannii, belonging to Thelocalyx, but $c f$. discussion on origins of Asian species below) or they may have originated in north Australia (probably subgen. Lasiocephala - 15, and sect. Prolifera - 3, both most diverse in Australia and with obviously Australian affinities). Lasiocephala shows interesting similarities to Bryastrum (including deciduous leaf laminae, a possible homology to the gemmae that are likewise developed from laminae), from which it differs by its divided styles. Chromosome counts confirm the affinity of the somewhat disputed D. banksii $(2 n=12)$ to the core of sect. Lasiocephala $(\mathrm{x}=6)$, and this count is also known from Bryastrum.

Some Australian groups (e.g. Coelophylla - 1, with an apparently primitive pollen type with 15-20 pores arranged in a circle on the proximal face, and Stelogyne - 1, with connate styles) take unclear intermediate positions, indicating possible links between the larger evolutionary lines, the former being closer to the Australian clade containing Ergaleium and Bryastrum, the latter approaching the northern clade containing sect. Drosera. Phycopsis (1), represented only by the polymorphic D. binata, stands at the base of the line leading to Ergaleium, with which it shares the plurifid styles, pollen morphology and DNA sequence homology, being different by the possession of stipules and by the lack of corms. DNA sequence comparison (Williams et al. 1994; Rivadavia et al. 2003) and phytochemistry (Culham \& Gornall 1994) confirm an affinity of D. binata to subgen. Ergaleium.

In south Africa a side branch still evidently related to the more recent lines of subgen. Drosera developed the roots into thickened storage organs, enabling the representatives to survive in seasonally drier habitats, a remarkable convergence to the corms formed in subgen. Ergaleium. However, the overwhelming majority of the African and American species are constituted by the derived sections of subgen. Drosera (together 48) which most probably also had a Gondwanan origin but not necessarily in Australia. The species are closely interrelated, and species limits are not always clear. Members with different seed morphology are interfertile, and they all share the chromosome base number of $\mathrm{x}=10$. Hybridization and introgression may account for some of the trouble in determining species in south Africa and elsewhere, and several taxa are probably of hybridogenic origin. Recent migrations of members of both sections across the American continent and a rather recent spread from there to temperate Eurasia are obvious. Much or all of the area of the three recent Eurasian species (D. intermedia, D. rotundifolia and D. anglica, all of which also being present and widespread in North America) was probably conquered during or 
after Pleistocene, and Drosera still behaves like a foreign element in the Eurasian flora, restricted to very specialized, typically postglacial habitats. In this context it is notable that the species now distributed throughout tropical and subtropical Asia (D. burmannii, D. peltata, D. indica, and D. spatulata) are all known from Australia (with the exceptions of an odd occurrence of $D$. rotundifolia in New Guinea and the recently described $D$. oblanceolata, which is probably a recent derivative of $D$. spatulata endemic to subtropical China). So the whole Drosera flora of Asia may be composed of originally North American (temperate) and Australian (subtropical and tropical) elements that have possibly invaded Asia only relatively recently from the northeast (possibly via a Behringian route) and from the east (possibly via New Guinea). Two of the Asian species ( $D$. indica and $D$. peltata replaced by its vicariant $D$. insolita, v.s.) are also represented in tropical and subtropical Africa, which would be a logical continuation of a westward migration.

The problems sketched during the discussion of generic composition are continued in macrosystematic considerations. Almost every system proposed has an individual "solution" for the placement of Droseraceae. A great deal of the difficulties was caused by the successive blurring of familial characteristics by inclusion of Dionaea or even Drosophyllum. Early systems saw an affinity (via Parnassia) to Crassulaceae and Saxifragaceae (Bentham \& Hooker 1862-1883), of which at least the affinity to Parnassia is adopted even by more recent approaches (Dahlgren 1980; Young 1982; Thorne 1983). The Sarraceniales problem (Melchior 1964, and successors) will be sketched under Sarraceniaceae (v.i.), and such a grouping, at least one of Droseraceae close to Sarraceniaceae is no longer maintained in recent systems. Some proximity to Nepenthaceae is conveyed by tetrad pollen and the fact that both families form acetogenic naphthoquinones, and the latter are present also in the Dioncophyllaceae, Ancistrocladaceae, Plumbaginaceae, all of which are members of Nepenthales in a revised circumscription (Schlauer 1997b). DNA sequence comparison favours a grouping of Droseraceae close to a Nepenthaceae + (Drosophyllaceae + (Dioncophyllaceae + Ancistrocladaceae)) clade (Meimberg et al. 2000). Because of the obvious similarities between the trapping leaves and in DNA sequence of Drosophyllum and Triphyophyllum (Dioncophyllaceae), a close affinity between these two genera (which are fundamentally different in the flower, however) seems possible. Parietal placentation, at least in Aldrovanda and Drosera has suggested affinity to Violaceae and/or Ochnaceae (DeCandolle 1823-1873; Wettstein 1935), but was dismissed as being decisive in later systems. All in all, it can be stated that in spite of a majority of traditional systems favouring proximity to Parnassiaceae, Crassulaceae, and Saxifragaceae (all being "rosid" families), the systematic position of the Droseraceae can now rather safely be allocated in Caryophyllidae.

Dioncophyllaceae

This family (3) is the only one which contains only one carnivorous genus among non-carnivorous ones. In early systems it was included in Flacourtiaceae (Dalla Torre \& Harms 1900-1907) and has not been altered in composition since its segregation (Airy Shaw 1952). The three genera are closely interrelated and exclusively tropical west African. Habropetalum and Triphyophyllum are sympatric but the latter is apparently more closely related to the disjunct Dioncophyllum (Meimberg et al. 2000). The feature of the fruits opening before seed maturity (paralleled to some degree in Anchietea and Decorsella, Violaceae), the seeds dramatically surpassing the ovary in size, is so unique in the plant kingdom that the family is readily characterized.

Parietal placentation was assumed (together with the striking fruit similarities) to support an affinity with Violaceae and Flacourtiaceae (Hutchinson 1973; Cronquist 1981; Takhtajan 1980). A position near Hypericaceae-Kielmeyeroideae and Nepenthaceae was discussed (Airy-Shaw 1952). The placement between Ochnaceae and Strasburgeriaceae (Melchior 1964) or more generally speaking, in Theales (Dahlgren 1980; Thorne 1983) also suggests a "dilleniid" affiliation ("Dilleniidae" in the sense applied in older classifications - incl. e.g. Theales and Malpighiales - cannot be upheld because the group was founded on artificial characters, and the component families belong to many independent lineages of dicotyledons, e.g. Rosidae, Ericidae, Asteridae). However, convincing similarities in pollen morphology and anatomy, and the common and unique presence of acetogenic naphthylisoquinoline alkaloids in both families leaves little doubt that Ancistrocladaceae (22, distributed throughout the tropics from west Africa to southeast Asia, but with notable disjunctions) are the most closely related sister group of Dioncophyllaceae (Dahlgren 1980). This was more recently also confirmed by DNA sequence comparison, indicat- 
ing also a close relationship to Drosophyllum (Cameron et al. 1995). Fossils from the Eocene of Raitschikha in the Amur district have been interpreted as Dioncophyllaceae seed (Fedotov 1982). If the assignment was accurate, this would indicate that the west African speciation of a formerly tremendously more widespread family must have taken place in relatively very recent time, while the family was much older. Such a situation could scarcely be explained by a simple chorological theory, and serious doubts about the identity of the fossil remain. Triphyophyllum has $2 n=24$ or 36 chromosomes, depending on the source.

Drosophyllaceae

Drosophyllum (1) is isolated both geographically (Portugal, southwest Spain, northwest Morocco) and systematically (v.s.). Although it is now placed rather remote from Droseraceae, it was originally described as a species of Drosera. Many different lines of evidence (v.s.) place it next to a clade containing Dioncophyllaceae and Ancistrocladaceae, both of which are well represented in tropical west Africa. The present disjunction was probably caused by the rather recent expansion of the Saharan desert, in which neither of the families can survive. With $2 \mathrm{n}=12$ chromosomes and its apparently likewise ancient relatives, Drosophyllum is probably an old relict (palaeoendemic) that may have originated in subtropical regions of Africa long before the expansion of the desert belt.

Nepenthaceae

This family contains only the genus Nepenthes (90), the circumscription of which has never presented taxonomists with difficulties because of the unique pitcher traps formed in all known species. Its subgeneric classification, on the other hand is one of the most complicated tasks in plant taxonomy, and the delimitation of species or natural species groups remains difficult. As far as it is known, all species are readily interfertile (sharing the uniform chromosome number of $2 \mathrm{n}=80$; Heubl \& Wistuba 1995), which has also resulted in numerous horticultural hybrids. The interrelationships of the numerous described species (summarized in Danser 1928 and Jebb \& Cheek 1997) have to be established by future research. So this will not be discussed in much detail here (for a summary of infrageneric classification until that date see Harms 1936). Genetic studies (Meimberg et al. 2001; see Figure 4) confirm a basal position of the western species (from Madagascar to Sri Lanka and the Khasi Hills in northeastern India), monophyly of a group of New Guinean species, of the relatives of $N$. tentaculata (Borneo and Sulawesi), and of a clade containing the moderately derived species with appendages on the lower surface of the lid (Regiae, Borneo, Philippines, Sulawesi, New Guinea). The bulk of described species (which apparently constitute

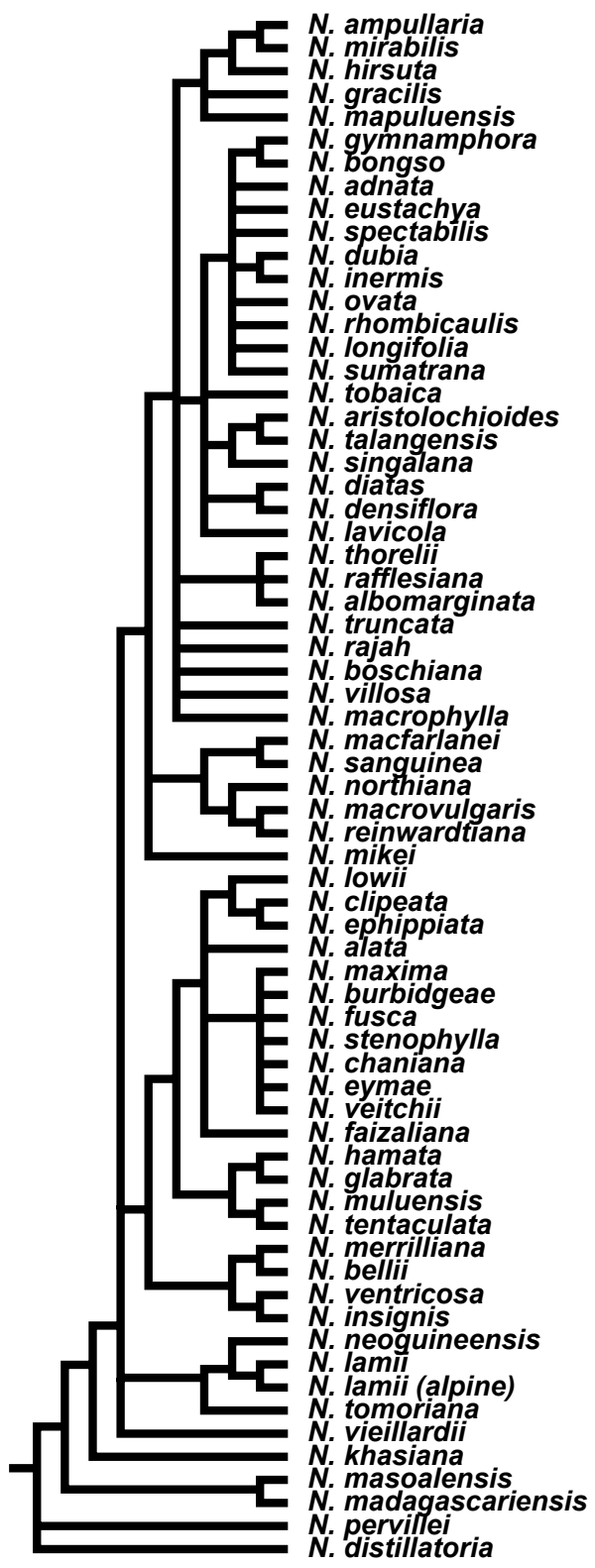

Figure 4: Phylogenetic tree of Nepenthaceae 
the most derived clade of the genus, mainly from Borneo and Sumatra) still have poorly understood mutual relationships. Possibly of evolutionary significance is the fact that pollen originally assigned to Droseraceae (Droseridites) from the Kerguelen islands has been tentatively transferred to Nepenthes more recently (Krutzsch 1985). In this context Droseridites parvus from the Mid Palaeocene of Assam (Sah \& Dutta 1974) should be considered as possible Nepenthes pollen. Fossil pollen assigned to Nepenthes has been discovered in the Mid Miocene of north Borneo (Anderson \& Müller 1975), and its presence here (a center of recent diversity, Schlauer 2000) is not surprising. But the assignment of European Tertiary pollen to the same genus (Krutzsch 1985) is at least as puzzling as the dubious Triphyophyllum seed from Siberia (v.i., recalling to some extent a similar discrepancy between fossil record and present distribution in Dipterocarpaceae and Clusiaceae). The total recent range of the family shows pronounced indicators of an east Gondwanan origin with strong tropical preferences, covering Madagascar ( $N$. madagascariensis and N. masoalensis), the Seychelles (N. pervillei), Sri Lanka (N. distillatoria), east India (Khasi Hills, $N$. khasiana, the only species north of the tropic of cancer!), continental and insular southeast Asia (most species), north Australia (only the widespread ( $N$. mirabilis), New Guinea (several species) and New Caledonia ( $N$. vieillardii). The fact that Nepenthaceae are absent from Africa (although the light seeds would seem capable of long distance dispersal) but present in extratropical India could indicate a time of origin at an early stage of the continental drift which has resulted in the present fragmentation of former Gondwanaland. This would mean that Nepenthaceae belonged to very early angiosperms. However, also other theories (e.g. integrating the European Tertiary pollen finds) are conceivable.

The macrosystematic placement of Nepenthaceae used to be subject to dispute similar to the situation in Droseraceae. While in the latter family its puzzling heterogeneity makes decisions difficult, Nepenthaceae are very uniform but the combination of primitive and derived characters (dioecious habit, perianth segments 4 without distinction between sepals and petals, stamina fused in a column, pollen in tetrads, placentation axial) isolates the family far from any hypothetical ally. This could, besides chorology, be a further indication of great phylogenetic age of the family as a whole (whereas some specialized endemic species seem to be rather young). Very indicative of the mentioned problems is the classification near Podostemaceae and Rafflesiaceae (Bentham \& Hooker 1862-1883), both families have likewise undergone fundamental transformations and reductions in floral morphology but the similarities are probably of a convergent nature. Even in subsequent systems (Wettstein 1935; Hutchinson 1973) Nepenthaceae were grouped with other assumedly primitive families. The inclusion of Nepenthaceae in the traditional Sarraceniales seems to be as artificial as in the case of Droseraceae (v.s.). An affinity to Droseraceae seems to be supported by pollen in tetrads and presence of naphthoquinones in both families, almost all other features remaining contradictory. Some recent systems place Nepenthaceae near Dioncophyllaceae (Dahlgren 1980; Young 1982; Thorne 1983). The latter is supported by several additional data, but the affinity is at the most rather loose, and the divergence must have taken place at an early stage of the evolution of the two families, i.e. possibly at an early stage of angiosperm evolution. A caryophyllid placement of the family is confirmed by DNA data (Meimberg et al. 2000).

\section{Rosidae (dicotyledon core group) - Oxalidales (see Figure 5)}

\section{Cephalotaceae}

This monotypic family is endemic to southwest Australia. No fossils have been attributed to Cephalotaceae, and no recent taxon was brought into close proximity of this family on morphological grounds. The precise place and time of origin are unknown. Thus, it can only be guessed to have been somewhere in Australia in habitats with ecological conditions comparable to the present range. Some hints can be expected from the macrosystematic position of Cephalotus (1). Despite some reduction in the number of ovules per carpel (leading to basal placentation), a great consent among various authors can be found as to a placement of Cephalotaceae close to Crassulaceae and Saxifragaceae (common traits being herbaceous habit, carpels distinct or basally connate,

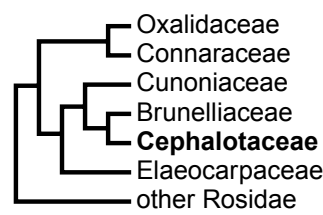

Figure 5: Phylogenetic tree of Oxalidales and Cephalotaceae 
tapering into the style, placentation axial or submarginal or basal, seeds with endosperm, flowers hypogynous or perigynous, actinomorphic), the similarities especially in the gynoecium being decisive. A grouping of Cephalotaceae quite remote from Saxifraga and Crassula but close to Platytheca (Tremandraceae), Ceratopetalum (Cunoniaceae), Eucryphia (Eucryphiaceae), or Oxalis (Oxalidaceae), as suggested by DNA sequence comparison (Albert et al. 1992) came, therefore, as a great surprise. A more recent study (Bradford \& Barnes 2001) identifies Brunellia (Brunelliaceae, South America) as the closest relative of Cephalotus (a grouping already suggested by Engler 1897). In most of the recent systems, some of these latter genera show at least some proximity to Saxifragales, but this grouping is not supported by genetic data. Anyway, a position at the base of the moderately derived "rosid" dicotyledons, and therefore originating from a line of rather old age (at least since Early Tertiary, possibly since Cretaceous) can be expected for Cephalotaceae. Given a northward movement of Australia since the supposed time of origin, the place of origin could have been situated in nowadays more northern regions of Australia (which are nowadays too arid for Cephalotus), where it most probably emerged from an early rosid, non-carnivorous progenitor. The development of the pitcher is unique among carnivorous ascidia, the lid being an excrescence of the base of the lamina (transversal zone of a peltate leaf), the rim being homologous to the apical leaf margin. Thus, any grouping together with other pitcher plants ( $c f$. Wettstein 1935) would be based on convergence rather than true phylogenetic relationship. All existing evidence indicates a very isolated position of Cephalotaceae with respect to other carnivorous plant families. Cephalotus has $2 \mathrm{n}=20$ chromosomes.

\section{Asteridae (sympetalae, dicotyledon crown group) - Ericales (see Figure 6)}

\section{Sarraceniaceae}

The Sarraceniaceae are at present a purely American family of high homogeneity, the holophyletic and monophyletic nature of which has never been doubted. The division into Heliamphoraceae (including only Heliamphora) and Sarraceniaceae s. str. (including Sarracenia and Darlingtonia) does reflect the relative distinctness between South and North American genera (Chrtek et al., 1992) but it does not seem appropriate to represent this by such a grave formal change (only a shift of ranks without significant taxonomic information). Morphological features are distributed in a reticulate fashion among the three genera so the course of evolution has been inferred in several different ways (Schnell 2002; Maguire 1978; Steyermark 1984). The geographic origin of the Sarraceniaceae would appear to be located in America. A recent fossil find from the Cretaceous of the Liaoning formation in China ( $\mathrm{Li} \mathrm{2005)}$ assigned to an ancestral genus of Sarraceniaceae and in some respects reminiscent of Heliamphora pitchers does, however, suggest an alternative scenario. Following this hypothesis, Sarraceniaceae would be the descendants of a subtropical Arcto-Tertiary element that is characteristic for many East Asian and East North American genera and families. While most of these disjunct taxa are more diverse in Asia than in America, the opposite would apply to Sarraceniaceae with no known recent Asian representatives. A trend of increasing complexity of the trapping devices in the order Heliamphora $(\mathbf{6}) \rightarrow$ Sarracenia $(\mathbf{8})$ $\rightarrow$ Darlingtonia (1) can be formulated, a simple marker of which being the increasing specialization of the pitcher mouth and the apical pitcher appendage (lid). This trend is not followed completely by floral morphology. Heliamphora, the apparently most primitive genus by foliar morphology, shows remarkable adaptations to specialized insect pollination, not paralleled by Darlingtonia or Sarracenia, which seem more advanced on the basis of leaf complexity. The chromosome numbers $(2 n=42$ in Heliamphora, 26 in Sarracenia, and 30 in Darlingtonia) do likewise not follow the trend

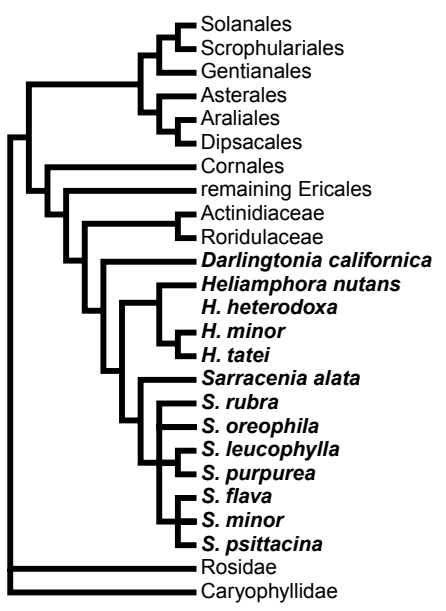

Figure 6: Phylogenetic tree of Ericales and Sarraceniaceae 
observed in foliar morphology. Being restricted to the Guyana Highlands, which are home to several ancient relicts (the mountains were exposed to erosion since the Cretaceous without significant folding or displacement), Heliamphora seems to indicate descent from a point close to the origin of the family. This was also deduced from comparative wood anatomy (DeBuhr 1977). Sarracenia, distributed in the temperate eastern part of North America from the Gulf coast to Canada, shows the largest area of distribution in the family. This i.a. reflects a much broader ecological amplitude indicative of a more derived descent. Finally, Darlingtonia, restricted to the Cascade Range in north California and adjacent southern Oregon, is probably a palaeoendemic element of this comparatively young (the most recent Cascadian orogeny occurred in Late Tertiary) mountain system. The pitcher of e.g. S. psittacina is remarkably similar to the one of Darlingtonia (while the flowers are rather different). Recent genetic investigations (Bayer et al. 1996) place Darlingtonia as a sister clade to a branch containing Heliamphora and Sarracenia, making a descent of Darlingtonia directly from Sarracenia unlikely if the latter is derived from Heliamphora, as generally assumed.

While it seems possible to sketch the evolution within Sarraceniaceae, the task of finding macrosystematic linkages of the family is much more difficult. The apparently primitive traits in floral morphology (e.g. a frequently pleiomerous androecium) have led some authors to assume a relationship with Papaveraceae (Bentham \& Hooker 1862-1883; Takhtajan 1980; Rouleau 1981). The carnivorous habit was the reason for inclusion of Sarraceniaceae in a variously remodelled order Sarraceniales/Nepenthales together with Nepenthaceae (also with pitcher traps, the apparent homology of which to Sarracenia pitchers being erroneous, however) and Droseraceae (entirely unrelated and different in almost every respect, apart from carnivory). This obviously paraphyletic assemblage enjoyed a remarkable longevity in systematic literature (Melchior 1964; Cronquist 1981). It was even argued that some homology existed between the different trapping devices (Markgraf 1955) although this had been clearly demonstrated not to be the case by earlier work (e.g. Troll 1939). Probably a "relict" of this tradition is the inclusion of Sarraceniaceae in or near Theales as a sister group of Lecythidaceae, Ochnaceae, and Hypericaceae, another sister being Nepenthaceae (Young 1982; Thorne 1983). Rather odd is the classification of Sarraceniales (together with Droseraceae but excluding Nepenthaceae) as a sister order of Podostemales, derived from a saxifragalean origin (Hutchinson 1973). Other recent classifications group Sarraceniaceae close to the Ericales, and Cornales on the basis of phytochemical similarities (Dahlgren 1980). Interestingly, DNA sequence comparison seems to support the placement near Ericales together with the likewise phytochemically similar Roridulaceae (Albert et al. 1992).

No clear affiliation can be proposed from the cited data except for a possible but loose affinity to Roridulaceae and Actinidiaceae (Schönenberger et al. 2005). This causes the question of age to remain essentially open as well. However, it seems evident that with the exception of Sarracenia purpurea, no taxon of Sarraceniaceae was involved in recent range extension, and the present genera represent relicts of a formerly more continuous or dynamic familial range. It has been pointed out that Heliamphora could not have migrated for the considerable distances which separate it from the other genera nowadays (Maguire 1978). But this would not have been necessary if the progenitors of the recent genera developed in northern (tropical) South America, Heliamphora remaining dependent on the conservative conditions of the Guyana Highlands, while Sarracenia was more or less able to migrate for long distances (a recent proof being the mentioned $S$. purpurea) and to cope with a seasonal temperate climate (depending on the species; marked differences in this respect can be seen within the genus even nowadays). It is more difficult to explain the origin of Darlingtonia, a montane palaeoendemic with features typical for Tertiary relicts. Perhaps, the South American progenitors were first separated ecologically (by sympatric differentiation), and with the onset of climatic changes this resulted also in geographic separation.

\section{Asteridae - Scrophulariales (Lamiales, Bignoniales) (Bremer et al. 2002; Müller et al. 2004; Olmstead et al. 2001; see Figure 7)}

\section{Byblidaceae}

This family contains only the genus Byblis (6). The sub-carnivorous genus Roridula (2), which has formerly been grouped within Byblidaceae (Hutchinson 1973; Cronquist 1981), is now usually regarded an independent family. In this strict sense, Byblidaceae inhabit Australia and New Guinea. Fossil seeds found in the Tertiary of Australia have been attributed to Byblidaceae 
(Conran \& Christophel 2004). Like in Cephalotaceae, an Australian origin can thus be assumed. The recent distribution (largest diversity in Northern Australia) may, however, indicate a somewhat more tropical preference (i.e. a place of origin somewhat closer to the equator). Byblidaceae have been associated with Droseraceae in early systems (Bentham \& Hooker 1862-1883), the main reason being the carnivorous habit by virtue of adhesive traps. But later on, the family has almost unanimously been placed close to the Pittosporaceae (especially to the genus Cheiranthera, which shares the irregular corolla and poricidal anthers with Byblis) or Tremandraceae (Hutchinson 1973). This or at least a "rosid" classification has been corroborated by several lines of evidence, e.g. wood anatomy (Carlquist 1976), and palynology (pollen tricolporate). However, DNA Sequence comparison (which corroborates a separation from Roridulaceae and placement of this latter family near Ericaceae) indicates a closer affinity of Byblidaceae to Scrophulariales or Solanales (Albert et al. 1992; Conran \& Dowd 1993). Compelling proof for a Scrophularialean placement comes from phytochemistry: Acteoside, a specific caffeic acid glycoside, has been identified as a characteristic chemical marker of Scrophulariales (Scogin 1992), it is present in all examined families (more than 140 genera) of this order, and only four incidences are known outside the order (in Asteraceae, Campanulaceae, Cucurbitaceae, and Magnoliaceae). The detection of acteoside in Byblis (Budzianowski et al. 1997; Schlauer et al. 2004) readily places the family in Scrophulariales. Flower structure (slight asymmetry, only basal sympetaly) suggests a position near the base of the order. The quite different morphology of the glandular hairs and the very weak sympetaly of Byblis do not support speculations about close affinities to Pinguicula (belonging to the same order) beyond pure convergence. Caryology is not uniform within Byblis $(2 \mathrm{n}=14,16,18$, 24, or 32 depending on species).

Lentibulariaceae

Even though the three genera included in this largest family of carnivorous plants have rather different trapping mechanisms, there is no doubt that they all belong to the same family which is monophyletic and holophyletic without non-carnivorous members ("The taxonomic limits of the Lentibulariaceae are not in question", Cronquist 1981: 975). Thus, speculation on paraphyly (Molau 1990) is essentially unjustified. The compelling evidence does, however, not stem from the common trait of carnivory. It can completely be deduced from floral morphology. The lentibulariacean flower is of a spurred personate type. This places the family readily in the order Scrophulariales. But unlike Plantaginaceae-Antirrhineae, the androecium is reduced to the two anterior stamens, indicating a possible closer relationship to Scrophulariaceae-Gratioleae, where this trait is common. The mentioned synapomorphies of Lentibulariaceae would already be sufficient for familial delimitation but the picture is completed by the universal (within Lentibulariaceae) and unique (within Scrophulariales) reduction of the ovary septum so that placentation becomes free-central (the originally two carpels still reveal themselves in the two remaining stigma lobes). The placentation type has even been argued to suggest a placement near 
Primulaceae (DeCandolle 1823-1873), but the distinctive corolla features are rather prohibitive of such. No recent system has positioned Lentibulariaceae outside Scrophulariales ("It is generally agreed that the Lentibulariaceae are derived from the Scrophulariaceae", Cronquist, l.c.). A position within Scrophulariales is also supported by gene sequence homology (Albert et al. 1992) and by the presence of acteoside (v.s. under Byblidaceae). The internal phylogeny of Scrophulariales is not well understood yet, but a descent of Lentibulariaceae from Scrophulariaceae or a related family is not at variance with non-morphological data. The fossil record of Lentibulariaceae is rather poor, and only pollen of aquatic Utricularia species (i.e. probably the most derived line in the family) is known - doubtfully since Oligocene from Cameroon (Psilostephanocolporites minor, Salard-Cheboldaeff 1978), and rather certainly since Upper Miocene from Mexico (Graham 1976), Senegal (Medus 1975), and Georgia (Cohen 1975). From increasing trap complexity and decreasing vegetative organization, a progressive arrangement Pinguicula (calyx lobes 5, true roots and leaves present) $\rightarrow$ Genlisea (calyx lobes 5, roots missing, leaves present) $\rightarrow$ Utricularia (calyx lobes 2 by coalescence, roots and leaves replaced by specialized stolons) seems plausible. The origin of the family should be sought where all three recent genera occur together, viz. in Central America (Guatemala to Colombia). Close to this probable center of origin, also the center of diversity of the assumedly most primitive genus, Pinguicula, can be located (Mexico, Caribbean, North American Gulf coast, Schlauer 2000).

Pinguicula (75) is widespread throughout the holarctic floristic kingdom with but few (and rather young) species. It also reaches Patagonia via the Andes, where few closely interrelated and typically vicariant species can be found. Pinguicula can be postulated to have originated in Early to mid-Tertiary. The genus has developed the extant subgenera except subgen. Pinguicula, which is of predominantly European origin (v.i.), in the new world before it spread to increasingly temperate, and finally arctic latitudes to the north. Another line can be postulated to have entered South America not until relatively recently (Pliocene) when the isthmus of Panama became a land bridge to central America again (having been submerged for the most time of the Tertiary). An (obviously secondary) center of diversification developed since Miocene in the high mountain regions surrounding the European Mediterranean (Casper 1966). From this, the nowadays most widely spread species (viz. P. vulgaris) and perhaps $P$. alpina have originated. $P$. vulgaris reached Siberia and North America, being replaced around the Pacific Ocean by the closely related P. macroceras. P. alpina inhabits the European Alps, Scandinavia, Siberia, and the Himalaya. Thus, the circumboreal prevalence of the generic range is a recent feature and not indicative of the generic origins. On the basis of floral morphology, four distinct lines were distinguished within Pinguicula: subgen. Isoloba (sections Isoloba, Cardiophyllum, Agnata, Discoradix, Homophyllum, and Heterophyllum, 28, mainly central and subtropical North America, few species in Atlantic and Mediterranean Europe), subgen. Temnoceras (sections Temnoceras, Ampullipalatum, Micranthus, and Nana, 15, central and Andine South America, few species from Europe to Siberia, reaching the Himalaya, north Korea, Japan, and Kamchatka), Orcheosanthus (originally described as a section within subgen. Pinguicula but obviously distinct, 21, central America), and subgen. Pinguicula (only sect. Pinguicula, 11, Eurasia, Mediterranean, and temperate North America). Chromosome counts only partially reflect the developments within the genus. Base numbers are $\mathrm{x}=8$ (characteristic for subgen. Pinguicula, and subgen. Temnoceras but also found in Orcheosanthus) and 11 (common in Isoloba and Orcheosanthus). The apparently primitive $P$. lusitanica (subgen. Isoloba) has $2 \mathrm{n}=12$, the lowest known count in the genus.

Genetic work (Cieslak et al. 2005; Kondo \& Shimai 2006; see Figure 8) places the subtropical North American and European Representatives of Isoloba together with the Andine species of Temnoceras (Ampullipalatum ) in a monophyletic clade at the base of the genus. The more derived clade is split between subgenus Pinguicula (without sect. Orcheosanthus) and all remaining species (central American/Caribbean species of Isoloba, Temnoceras, and Orcheosanthus, and the relatives of the Eurasian P. alpina - Micranthus \& Nana). It thus appears that chorology is much more indicative of the phylogeny of the genus than is floral morphology. It is, however, surprising that none of the basal species occurs in central America (the place with most present diversity in the genus).

The small and highly uniform genus Genlisea (20) is confined to the tropics of America and Africa (including Madagascar, Fischer et al. 2000), probably with a center of origin close to or 
south of the one of Pinguicula (viz. central or northern South America), where still local centers of diversity are present. However, the seemingly more primitive species (sharing the laterally or longitudinally bivalvate capsule with Pinguicula), classified (Fromm-Trinta 1977) as sect. Tayloria (3), are nowadays confined to Brasil (NB: it is possible that both recent dehiscence types in this genus are of a derived nature, $c f$. also the various dehiscence types present in Utricularia,

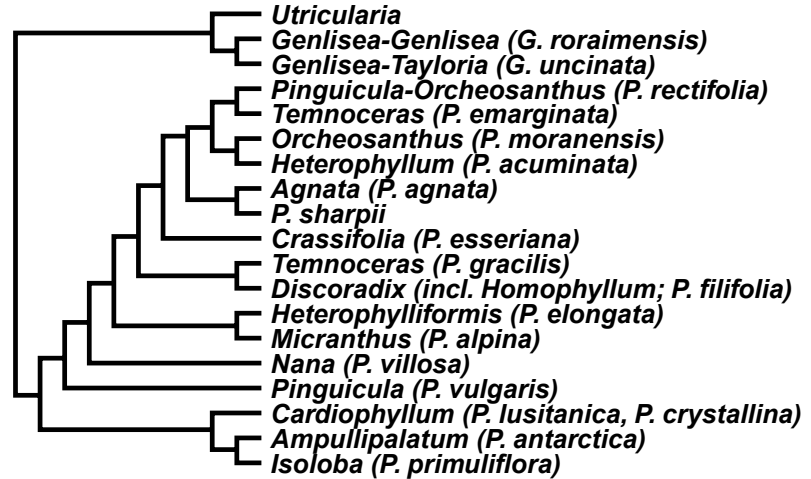

Figure 8: Phylogenetic tree of Lentibulariaceae showing detailed relationships within Pinguicula and Genlisea displaying parallelism and convergence). The remaining species are marked by circumscissile capsules and are classified as sect. Genlisea (17). The present range of sect. Tayloria may reflect a relict nature (if this section was really the more primitive one). The tropical Afro-American distribution is suggestive of a rather old age of the genus, and overall morphology points at an early divergence from the common ancestors with Pinguicula.

The genus Utricularia (215) obviously emerged from a line closer to Genlisea probably after Pinguicula and Genlisea had diverged from each other. In fact, Utricularia can be deduced theoretically by neoteny from Genlisea (which in turn is also partially true for Genlisea from Pinguicula). The very elaborated suction traps of Utricularia constitute a ready and convincing means for generic separation. Being very probably the most derived and youngest genus of Lentibulariaceae, Utricularia shows a remarkable diversity of vegetative structure, trap (the mechanism remaining uniform), pollen and seed morphology, and capsule dehiscence, which allow grouping into sections, but which make natural phylogenetic arrangements rather difficult on the other hand (Taylor 1989). The origins of the nowadays very widespread genus (the largest of all carnivorous plants by species number and distribution) are somewhat obscure. The reduction of bracteoles at the base of the pedicels can be assumed to have occurred but once (with the notable exception of the otherwise obviously more primitive $U$. heterosepala - a doubtless member of sect. Oligocista) during the course of evolution within Utricularia, and it can be taken as a good marker for infrageneric classification. Thus, two large groups of sections can be defined. The more primitive ones share the presence of distinct bracteoles and predominance in tropical zones with Genlisea, the more derived and specialized ones lacking bracteoles constitute a younger group with (secondarily) wide distribution, comparable with the situation in subgen. Pinguicula of Pinguicula.

The essentially Australian (few species reaching New Caledonia and New Zealand) and closely interrelated sects. Polypompholyx (2), Tridentaria (1), and Pleiochasia (33) are commonly regarded as primitive (foliar organs more or less rosulate, flowers in pleiochasia, pollen 3-colporate with discrete endoapertures) although these do not meet geographically with any recent species of Genlisea, so it is not entirely clear if they actually are the phylogenetically oldest representatives of Utricularia.

A group of only little derived sections (Australes - 3, Australian, Meionula - 3, Australian and Asian, Nigrescentes - 3, Australian, Asian, and African, and Calpidisca - 10, Asian and African, only one species also disjunct in Mexico) can be assumed to be closely related to the foregoing group, showing similarities in trap structure and pollen morphology (in sect. Nigrescentes). Meionula and Calpidisca pollen structure (zonocolporate with 3 to 8 ectoapertures) approaches that of Oligocista and its allies Benjaminia and Avesicarioides (Lobreau-Callen et al. 1999).

The sections Kamienskia (1, China), Phyllaria (13, Asia, only one species also in Africa), and Oliveria (1, Africa and Madagascar) share dorsiventrally flattened pedicels and generally a reduced number of arms in the glands on the internal trap surface with sect. Oligocista (v.i.). 
Kamienskia does also have a similar trap and bract/bracteole morphology. Its pollen is similar to that of Oliveria and Oligocista, whereas the pollen of Phyllaria is similar to that of Stomoisia. All three sections differ from Oligocista by the conspicuously unequal calyx lobes (the upper being larger). Phyllaria and Oliveria approach Nigrescentes by their basisolute bracts, apically extended placenta, and appendiculate seeds.

The section Lloydia (1, Asian, African, and American) is probably most closely related to Calpidisca, but with 7-10-colporate pollen it approaches sections Psyllosperma and Foliosa (v.i.), while its basisolute bracts are reminiscent of the more primitive sect. Nigrescentes (v.s.).

With its pronounced anterior trap appendage, sect. Candollea (1, east African) is apparently most closely related to sect. Aranella (9), which is apparently the most primitive section with a prevalence in the new world (only one species out of nine also reaching Africa). It is rather distinct in several features, including trap structure and fimbriate bracts and/or sepals. Sections Aranella and Stylotheca (v.i.) share zonocolporate pollen with 4 to 7 ectoapertures. The related but likewise distinct (filiform unicellular trap appendages) sect. Martinia (1) is restricted to South America.

By the number of species, a further large group of sections (viz. Orchidioides - 9, Iperua - 5, Stomoisia - 2, Stylotheca - 1, Choristothecae - 2, Benjaminia - 1, all American (one species of Stomoisia has recently also been discovered in west Africa), Oligocista-37, pantropical, Chelidon - 1 and Avesicarioides - 2, African, and Enskide - 2, tropical east Asian and north Australian) exhibits numerous features that appear plesiomorphic, but until their mutual relationships can be assessed more precisely, they are left at an intermediate position of the primitive infrageneric line with bracteoles (the only species that belongs here but lacks bracteoles, U. heterosepala, was already mentioned above). Some species (of Chelidon, Orchidioides, and Iperua) are adapted to epiphytic life with tubers as storage organs. All these share breviaxial pollen with sections Stomoisia and Phyllaria (v.s.), of which some species are interestingly likewise adapted to epiphytic or epilithic life. Sect. Avesicarioides is similar to Oligocista in all taxonomically relevant respects (bracteoles present, pedicels dorsiventrally flattened, pollen 4-6-colporate with narrow ectoaperture). Its adaptation to rheophytic habit causes superficial similarities to some more derived, likewise rheophytic American sections lacking bracteoles (v.i.), but these are obviously convergent and not due to a close phylogenetic relationship. Sect. Choristothecae, likewise composed of rheophytic species with bracteoles, displays similarities to the terrestrial Sect. Stylotheca (especially an elongation of the style not known in any other member of Lentibulariaceae), and it has 4-aperturate pollen (very distinct from the pollen with 8 or more ectoapertures found in the rheophytic species lacking bracteoles, v.i.), so sect. Choristothecae may represent a neotropical counterpart to Avesicarioides, demonstrating that rheophytic habit alone is obviously not a character defining only a single, monophyletic group in Utricularia (contrary to the opinion put forward in Taylor 1989).

The sects. Psyllosperma (9) and Foliosa (3), all American (predominantly tropical), exhibit a pollen type (8- or frequently more-colporate) that is characteristic for the group of sections uniformly lacking bracteoles (v.i.). This is especially noteworthy because in all representatives of sect. Foliosa and in some of sect. Psyllosperma the bracteoles are partially fused with their supporting bract, perhaps representing a transitional condition. On the other hand, trap morphology (with a densely glandular trap entrance) is very different from the species lacking bracteoles and rather reminiscent of the supposedly more primitive sections Nigrescentes, Calpidisca, and Lloydia (v.s.), of which only two widespread species (U. livida and U. pubescens, both with a comparatively high count of ectoapertures on their pollen) co-occur with Psyllosperma and Foliosa (in Central or Southern America, respectively). The latter two sections with their manifold relationships possibly represent a crucial (relictual?) intermediate stage in the evolution of the genus.

The more derived line of Utricularia that always lacks bracteoles and that is further characterized by subequiaxial zonocolporate pollen with 8 or more ectoapertures, is composed of principally two distinct groups. The first, apparently more primitive one (including sects. Sprucea - 1, Avesicaria - 2, Mirabiles - 2, Steyermarkia - 2, Lecticula - 2, entirely American, Setiscapella - 9, pantropical and subtropical, but predominantly American, and Nelipus - 3, east Asian and north Australian) shares uniformly basisolute or tubular (in sect. Lecticula) bracts and terrestrial or rheophytic (Avesicaria, Mirabiles) habit with mostly undivided foliar organs. The sections Avesicaria and Mirabiles are further characterized by transversally flattened placentae 
supported by a long stalk that originates from the ovary base, indicating mutual close affinities. The recent distribution pattern of sections lacking bracteoles (and their potential ancestors among sects. Foliosa and Psyllosperma, v.s.) strongly indicates an origin of their immediate common progenitor in (probably South) America, and subsequent waves of global range extensions in sects. Setiscapella (only few species outside America) and Utricularia (v.i.). The recent range of sect. Nelipus can possibly be explained by a comparatively recent origin (?from sect. Setiscapella), or alternatively by long-range dispersal and extinction in its original range (?America). Neither variant is entirely comforting, and further study is required.

The supposedly most advanced group (consisting of sects. Utricularia - 35, almost cosmopolitan and Vesiculina - 3, American) consists of predominantly aquatic plants with much divided foliar organs and frequently freely suspended floating stems. Of the whole genus, only sect. Utricularia has reached wide distribution in the Holarctis. Three minute American species (U. biovularioides, $U$. naviculata, and $U$. olivacea) included in sect. Utricularia by Taylor (1989) are characterized by 7-10-colporate pollen (most of the remaining species in the section have 10-20-colporate pollen) and the lack of free-ending stolon segments (all segments are terminated by a trap), which may warrant segregation in a distinct section.

Until now, the scant caryological data on Utricularia are not conclusive (base numbers of $\mathrm{x}=7,9,10$, and 11 , only 28 species counted so far). Genetic data (rps16 and trnL-F, Jobson \& Albert 2002; see Figure 9) support a basal position of sections Polypompholyx and Pleiochasia, sister to the remaining genus that is divided into two large clades roughly following the division according to bracteole reduction (with the exception of sections Orchidioides and Iperua that group as a sister clade to Psyllosperma and Foliosa rather than as a satellite of Oligocista as discussed above). The assumedly more primitive clade (bracteoles present, pollen with few appertures) has Aranella as sister to the remaining sections, compatible with a very primitive position as discussed above. A pair of clades, viz. Phyllaria + Nigrescentes and an unresolved group containing Calpidisca, Australes, and Lloydia is opposed to Oligocista and its allies (so far only Benjaminia, Stomoisia, and Enskide have been analyzed, so the picture is incomplete here). In the derived clade, the four sections Orchidioides, Iperua, Psyllosperma, and Foliosa form a common group that is sister to the bracteole-free sections. In these, the close affinity of Avesicaria, and Setiscapella, and a separation of Biovularia from the remainder of sect. Utricularia (and grouping Biovularia closer to Vesiculina) is supported.

References to all chromosome counts mentioned and a survey of all described taxa of carnivorous plants can be found on the World Wide Web (Schlauer \& Walker 2000).

Note: This paper was presented at the 6th Conference of International Carnivorous Plant Society, June 1-5, 2006, Frostburg, Maryland, USA, and cannot reflect the most recent state of knowledge.

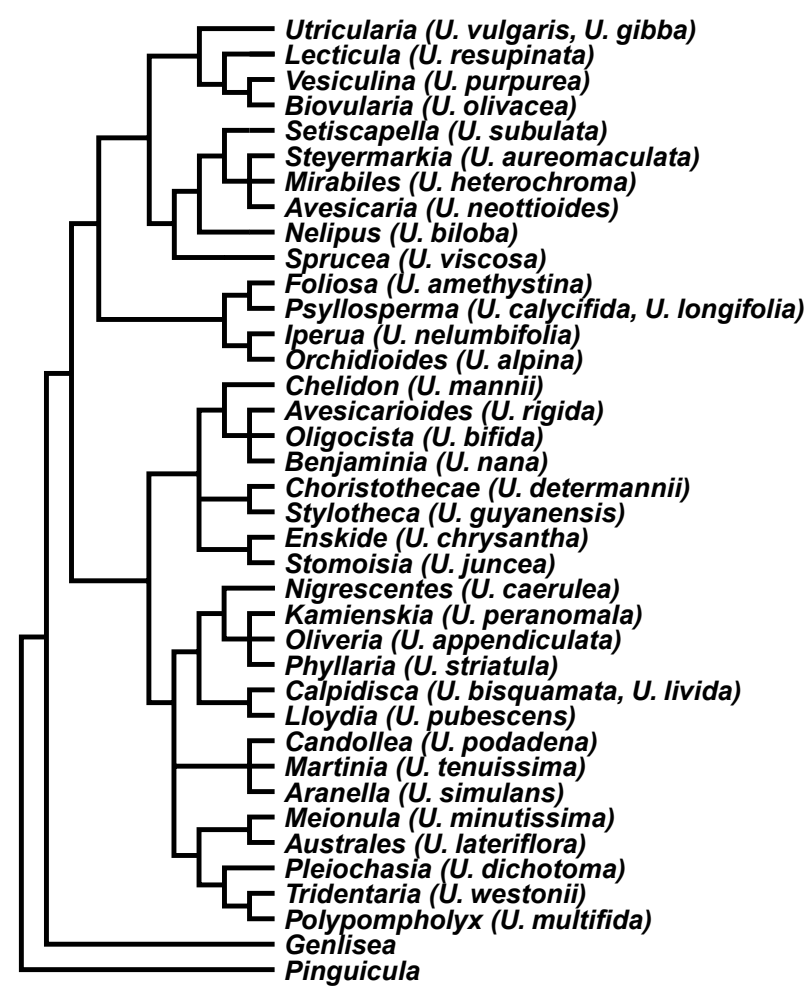

Figure 9: Phylogenetic tree of Utricularia 
References

Airy Shaw, H.K. 1952. On the Dioncophyllaceae, a remarkable new family of flowering plants. Kew Bull. 1951: 327-347.

Albert, V.A., Williams, S.E., and Chase, M.W. 1992. Carnivorous plants: Phylogeny and structural evolution. Science 257(5076): 1491-1495.

Anderson, J.A.R., and Müller, J. 1975. Palynological study of a Holocene peat and a Miocene coal deposit from NW Borneo. Rev. Palaeontol. Palynol. 19: 291-351.

Bayer, R.J., Hufford, L., and Soltis, D.E. 1996. Phylogenetic relationships in Sarraceniaceae based on rbcL and ITS sequences. System. Bot. 21: 121-134.

Bentham, G., and Hooker, J.D. 1862-1883. Genera Plantarum, London.

Bradford, J.C., and Barnes, R.W. 2001. Phylogenetics and classification of Cunoniaceae (Oxalidales) using chloroplast DNA sequences and morphology. System. Bot. 26: 354-385.

Bremer, B., Bremer, K., Heidari, N., Erixon, P., and Olmstead, R.G. 2002. Phylogenetics of asterids based on 3 coding and 3 non-coding chloroplast DNA markers and the utility of non-coding DNA at higher taxonomic levels. Mol. Phylogen. Evol. 24: 274-301.

Budzianowski, J., Ratajczak, L., Kukulczanka, K., and Kromer, K. 1997. Phenolic compounds of Sarracenia alata and Byblis liniflora from in vitro cultures. 45th Ann. Congr. Soc. Med. Pl. Res. Regensburg, Program \& Abstracts: C21.

Cameron, K.M., Chase, M.W., and Swensen, S.M. 1995. Molecular evidence for the relationships of Triphyophyllum and Ancistrocladus. Am. J. Bot. 82(6): 117-118.

Cameron, K.M., Wurdack, K.J., and Jobson, R.W. 2002. Molecular evidence for the common origin of snap-traps among carnivorous plants. Am. J. Bot. 89: 1503-1509.

Carlquist, S. 1976. Wood anatomy of the Byblidaceae. Bot. Gaz. 137: 35-38.

Casper, S.J. 1966. Monographie der Gattung Pinguicula. Biblioth. Bot. 127/128.

Chrtek, J., Slavikova, Z., and Studnicka, M. 1989. Beitrag zur Leitbündelanordnung in den Kronblättern von ausgewählten Arten der fleischfressenden Pflanzen. Preslia 61: 107-124.

Chrtek, J., Slavikova, Z., and Studnicka, M. 1992. Beitrag zur Morphologie und Taxonomie der Familie Sarraceniaceae. Preslia 64: 1-10.

Cieslak, T., Polepalli, J.S., White, A., Müller, K., Borsch, T., Barthlott, W., Steiger, J., Marchant, A.. and Legendre, L. 2005. Phylogenetic analysis of Pinguicula (Lentibulariaceae): Chloroplast DNA sequences and morphology support several geographically distinct radiations. Am. J. Bot. 92: 1723-1736.

Cohen, A.D. 1975. Peats from the Okefenokee swamp-marsh complex, Geosci. \& Man 11: 123-131.

Conran, J.G., and Christophel, D.C. 2004. A fossil Byblidaceae seed from Eocene South Australia. Intern. J. Pl. Sci. 165: 691-694.

Conran, J.G., and Dowd, J.M. 1993. The phylogenetic relationships of Byblis and Roridula inferred from partial 18s ribosomal RNA sequences. Pl. Syst. Evol. 188: 73-86.

Cronquist, A. 1981. An Integrated System of Flowering Plants. Columbia Univ. Press, New York.

Culham, A., and Gornall, R.J. 1994. The taxonomic significance of naphthoquinones in Droseraceae. Biochem. Syst. Ecol. 22: 507-515.

Dahlgren, R.M.T. 1980. A revised system of the angiosperms. Bot. J. Linn. Soc. 80: 91-124.

Dalla Torre, G.G. de, and Harms, H. 1900-1907. Genera Siphonogamarum ad Systema Englerianum Conscripta.

Danser, B.H. 1928. The Nepenthaceae of the Netherlands Indies. Bull. Jard. Bot. Buitenzorg.

DeBuhr, L. 1977. Wood anatomy of the Sarraceniaceae. Pl. Syst. Evol. 128: 159-169.

DeCandolle, C. P. 1823-1873. Prodromus systematis naturalis regni vegetabilis. Paris: Masson.

Degreef, J.D. 1997. Fossil Aldrovanda. Carniv. Pl. Newslett. 26: 93-97.

Engler, A. 1897. Brunelliaceae, in A. Engler and K. Prantl: Die natürlichen Pflanzenfamilien. Nachtrag zu Tl. III: 184. Engelmann, Leipzig.

Fedotov, V.V. 1982. The genus Dioncophyllites in the Eocene flora of Raitschikha from the Amur district. Bot. Zhurn. 67(7): 985-987.

Fischer, E., Porembski, S., and Barthlott, W. 2000. Revision of the genus Genlisea (Lentibulariaceae) in Africa and Madagascar with notes on ecology and phytogeography. Nordic J. Bot. 20: 291-318.

Fromm-Trinta, E. 1977. Tayloria Fromm-Trinta - Nova Seção do gênero Genlisea St.-Hil. (Lentibulariaceae), Boletim do Mus. nac. Rio de Janeiro n. ser. Bot. 44: 1-4. 
Graham, A. 1976. Studies in neotropical palaeobotany. II. The Miocene communities of Veracruz, Mexico. Ann. Mo. Bot. Gard. 63: 787-842.

Harms, H. 1936. Nepenthaceae, in A. Engler and K. Prantl: Die natürlichen Pflanzenfamilien, 2. ed. 17b: 701-703. Engelmann, Leipzig.

Heubl, G., and Wistuba, A. 1995. A cytological study of the genus Nepenthes L. (Nepenthaceae). Sendtnera 4: 169-174.

Hoshi, Y., and Kondo, K. 1998a. Chromosome differentiation in Drosera, subgenus Rorella, section Rossolis. Cytologia 63: 199-211.

Hoshi, Y., and Kondo, K. 1998b. A chromosome phylogeny of the Droseraceae by using CMADAPI fluorescent banding. Cytologia 63: 329-339.

Huang, T.-C. 1978. Miocene palynomorphs of Taiwan II. Tetrad grains. Bot. Bull. Acad. Sinica 19: $77-81$.

Hutchinson, J. 1973. The Families of Flowering Plants. 3. ed. Clarendon, Oxford.

Jebb, M., and Cheek, M. 1997. A skeletal revision of Nepenthes (Nepenthaceae). Blumea 42: 1106.

Jobson, R.W., and Albert, V. 2002. Molecular rates parallel diversification contrasts between carnivorous plant sister lineages. Cladistics 18: 127-136.

Kondo, K., and Shimai, H. 2006. Phylogenetic analysis of the northern Pinguicula (Lentibulariaceae) based on internal transcribed spacer (ITS) sequences. Acta Phytotax. Geobot. 57: 155-164.

Krutzsch, W. 1970. Zur Kenntnis fossiler disperser Tetradenpollen, Paläontol. Abh. B3: 399-433.

Krutzsch, W. 1985. Über Nepenthes-Pollen (alias "Droseridites" p. p.) im europäischen Tertiär. Gleditschia 13: 89-93.

Li, H. 2005. Early Cretaceous Sarraceniacean-like pitcher plants from China. Acta Bot. Gallica 152: $227-234$.

Lobreau-Callen, D., Jérémie, J., and Suarez-Cervera, M. 1999. Morphologie et ultrastructure du pollen dans le genre Utricularia L. (Lentibulariaceae). Can. J. Bot. 77: 744-767.

Maguire, B. 1978. Sarraceniaceae (Bot. of the Guayana Highland X). Mem. NY. Bot. Gard. 29: 36-62.

Markgraf, F. 1955. Über Laubblatt-Homologien und verwandtschaftliche Zusammenhänge bei Sarraceniales. Planta (Berlin) 46: 414-446.

Medus, J. 1975. Palynologie de sédiments Tertiaires du Sénégal méridional. Pollen \& Spores 17: 545-608.

Meimberg, H., Dittrich, P., Bringmann, G., Schlauer, J., and Heubl, G. 2000. Molecular phylogeny of Caryophyllidae s.l. based on MatK sequences with special emphasis on carnivorous taxa. Plant Biol. 2: 218-228.

Meimberg, H., Wistuba, A., Dittrich, P., and Heubl, G. 2001. Molecular phylogeny of Nepenthaceae based on cladistic analysis of plastid trnK intron sequence data. Plant Biol. 3: 164-175.

Melchior, H. (ed.) 1964. Englers Syllabus der Pflanzenfamilien, 12. ed. Borntraeger, Berlin.

Mildenhall, D.C. 1980. New Zealand late Cretaceous and Cenozoic plant biogeography: a contribution. Palaeogeogr., Palaeoclimatol., Palaeoecol. 31: 197- 233.

Molau, U. 1990. The genus Bartsia. Opera Bot. 102.

Müller, K., Borsch, T., Legendre, L., Porembski, S., Theisen, I., and Barthlott, W. 2004. Evolution of carnivory in Lentibulariaceae and the Lamiales. Plant Biol. 6: 477-490.

Olmstead, R.G., DePamphilis, C.G., Wolfe, A.D., Young, N.D., Elisons, W.J., and Reeves, P.A. 2001, Disintegration of the Scrophulariaceae. Am. J. Bot. 88: 348-361.

Rivadavia, F., Kondo, K., Kato, M., and Hasebe, M. 2003. Phylogeny of the sundews, Drosera (Droseraceae), Based on chloroplast rbcL and nuclear 18S ribosomal DNA sequences. Am. J. Bot. 90: 123-130.

Rouleau, E. 1981. Guide to the Generic Names Appearing in the Index Kewensis and its 15 Supplements. Châtelain, Cowanville.

Sah, S.C.D., and Dutta, K. 1974. Palynostratigraphy of the sedimentary formations of Assam. 3. Biostratigraphic zonation of the Cherra Formation of South Shillong Plateau. Palaeobotanist 21: 42-47.

Salard-Cheboldaeff, M. 1978. Sur la palynoflore Maestrichtienne et Tértiaire du bassin sédimentaire littoral du Cameroun. Pollen \& Spores 20: 215-260. 
Schlauer, J. 1996. A dichotomous key to the genus Drosera L. (Droseraceae). Carniv. Pl., Newslett. 25: 67-88.

Schlauer, J. 1997a. Fossil Aldrovanda - Additions. Carniv. Pl. Newslett. 26: 98.

Schlauer, J. 1997b. "New" data relating to the evolution and phylogeny of some carnivorous plant families. Carniv. Pl. Newslett. 26: 34-38.

Schlauer, J. 2000. Global carnivorous plant diversity. Carniv. Pl. Newslett. 29: 75-82.

Schlauer, J., Budzianowski, J., Kukulczanka, K., and Ratajczak, L. 2004. Acteoside and related phenylethanoid glycosides in Byblis liniflora Salisb. Plants propagated in vitro and its systematic significance. Acta Soc. Bot. Polon. 73: 9-15.

Schlauer, J., and Walker, R. 2006. Carnivorous Plant Database. http://www.omnisterra.com/botany/cp/data/jans.db

Schnell, D.E. 2002. Carnivorous Plants of the United States and Canada, 2. ed.. Timber Press.

Schönenberger, J., Anderberg, A.A., and Sytsma, K.J. 2005. Molecular phylogenetics and patterns of floral evolution in the Ericales. Intern. J. Pl. Sci. 166: 265-288.

Scogin R. 1992. The distribution of acteoside among angiosperms. Biochem. Syst. Ecol. 20: 477480.

Steyermark, J.A. 1984. Venezuelan Guyana. Ann. Missouri Bot. Gard 71: 302-312.

Takahashi, H., and Sohma, K. 1982. Pollen morphology of the Droseraceae and its related taxa. Sci. Rep. Tohoku Univ. 4. ser. Biol. 38: 81-156.

Takhtajan, A. 1980. Outline of the classification of flowering plants. Bot. Rev. 46: 225-359.

Taylor, P. 1989. The Genus Utricularia. Kew Bull. Add. Ser. 18.

Thorne, R.F. 1983. Proposed new realignments in the angiosperms. Nordic J. Bot. 3: 85-117.

Troll, W. 1939. Vergleichende Morphologie der höheren Pflanzen. Borntraeger, Berlin.

Truswell, E.M., and Marchant, N. 1986. Early Tertiary pollen of probable Droseracean affinity from central Australia. Special Papers in Palaeontology 35: 163-178.

Wettstein, R. von. 1935. Handbuch der systematischen Botanik, 4. ed. Deuticke, Leipzig.

Williams, S.E., Albert, V.A., and Chase, M.W. 1994. Relationships of Droseraceae: A cladistic analysis of rbcL sequence and morphological data. Am. J. Bot. 81(8): 1027-1037.

Young, D.A. 1982. The Young system. Phytologia 51: 65-156.

\section{THE ICPS SEED BANK an exclusive member benefit}

The International Carnivorous Plant Society offers its members exclusive access to a variety of carnivorous plant seeds. Seeds are ordered online at the ICPS Store:

\section{http://icps.clubexpress.com/}

The Seed Bank cannot exist without seed donations. Information about growing carnivorous plants from seed and donating seeds to the Seed Bank are at the ICPS public web site:

\section{http://www.carnivorousplants.org/seedbank}

If you do not have access to the Internet, please send seed order form requests to:

International Carnivorous Plant Society

1564-A Fitzgerald Drive, PMB 322

Pinole, CA 94564-2229

JOHN BRITTNACHER, Seed Bank Manager, john@ carnivorousplants.org 